\title{
Reserved Seats, Political Parties, and Minority Representation
}

\author{
CHRISTINA ISABEL ZUBER \\ Fachbereich Politik- und Verwaltungswissenschaft, Universität Konstanz, Germany
}

\begin{abstract}
This article seeks to clarify the relationship between reserved seats filled through competitive elections, political parties, and substantive minority representation. It argues that the party affiliation of the minority representative moderates the impact of reserved seats on substantive representation since minority and party constituencies can cross-pressure a representative or, in the case of overlap, can allow her to cater to party and minority interests simultaneously. Drawing on empirical examples, the article first classifies party affiliations along the criterion of overlap between minority interests and party appeal into five categories: 'coinciding ethnic' parties, 'multi-ethnic' parties, 'partial ethnic' parties, 'other ethnic' parties, and 'non-ethnic' parties. Hypotheses about how these affiliations affect a reserved-seat representative's willingness to act for the minority are later developed, expecting a strong positive effect of the coinciding ethnic party, a weak positive effect for multi- and partial ethnic parties, a negative effect for other ethnic parties, and no effect for non-ethnic party affiliation.
\end{abstract}

\section{Introduction}

The fact that a man or an assembly is a very good descriptive representation does not automatically guarantee that they will be good representatives in the sense of acting for, that their activity will really be representing. In the realm of action, the representative's characteristics are relevant only insofar as they affect what he does. (Pitkin, 1967, p. 142)

More than 30 countries worldwide reserve seats in their national parliaments for representatives of minority groups (Krook \& O’Brien, 2010, pp. 257-258). Including representatives of all politically relevant groups into the legislature can-in itself-be considered a normatively desirable goal that representative democracies should aim to achieve (Norris, 2006, p. 198). However, seats for minorities are often introduced in the additional hope that these representatives will not only stand for, but also act for, members of the society that identify with a minority group. In Bosnia and Herzegovina, for example, the case studied in more detail in the empirical contributions to this Special Section, the Law on Minorities states that 'the representatives of national minorities in the governing

Correspondence Address: Christina Isabel Zuber, Fachbereich Politik- und Verwaltungswissenschaft, Universität Konstanz, Universitätsstrasse 10, 78464 Konstanz, Germany. Email: mail@christinazuber.com 
structures are the representatives of all national minorities and are obliged to protect the interests of all national minorities' (Law on Minorities, Article 20, Paragraph 3, quoted by Hodžić, 2011, p. 25, emphasis added). The classical literature on representation in the tradition of Hanna Pitkin has, however, questioned whether a straight causal arrow can be drawn from the placement into legislatures of individuals mirroring the characteristics of a group of voters to parliamentary behaviour that will indeed benefit this group (Pitkin, 1967, p. 142). To use Pitkin's own terminology, it is not clear why the descriptive representation of minority characteristics should lead to the substantive representation of minority interests and whether institutional designers can manipulate what legislatures do by changing the way they are composed.

Empirically, even the vast literature on gender quotas has only recently begun to analyse the impact of quotas 'beyond numbers' (Krook \& Zetterberg, 2014, p. 5). The literature on minority quotas (including reservations) is a lot less extensive, leaving these institutions 'little understood' in general (Bird, 2014, p. 12). Whereas a range of contributions aim to provide systematic classifications of the universe of cases (Bird, 2014; Krook \& O'Brien, 2010; Meier, 2009; Reynolds, 2005; Vukelic, 2012) few studies analyse the causal effects of reservations on representation or other outcomes, such as democratic stability and minority empowerment (for the latter, see Lončar, in press).The literature investigating the impact of reserved seats on substantive representation to a large extent consists of studies taking advantage of sub-national variation in India and applying a distributive operationalisation of acting in the minority interest, be it in terms of public goods or private transfers. Interestingly, however, scholars have come up with diverging results even when studying the Indian case. On the one hand, Duflo (2005) and Chattopadhyay and Duflo (2004) find that reservation encourages the redistribution of public goods to those social groups who formed the basis for the reservation, be they scheduled castes, scheduled tribes, or women. On the other hand, and on the basis of methodological refinements, two more recent studies find that neither including representatives of scheduled castes in state parliaments (Jensenius, 2013, Chapter 8) nor reserving the office of the village council president for a member of this group (Dunning \& Nilekani, 2013) has a redistributive effect.

These recent contributions unanimously conclude that 'parties matter'. Minority representatives prioritise representing their party over representing the minority (Jensenius, 2013 , p. 3). As a consequence, party affiliation can moderate the redistributive effect of reserved seats. If minority representatives are overwhelmingly members of multi-ethnic parties, as in the case of India, redistribution along party lines only benefits groups targeted with reserved seats inter alia, but not specifically, so no systematic effect is obtained. A similar line of argument can be found in Hodžić's (2011, pp. 27-28) analysis of the Bosnian case: if minority representatives are overwhelmingly members of ethnic parties targeting one of the three constituent peoples, redistribution along party lines can be expected to exclude from the benefits minorities belonging to different ethnic groups.

This article seeks to put these recent findings on firmer theoretical ground by clarifying the relationship between reserved seats filled through competitive elections, ${ }^{1}$ political parties, and substantive minority representation. I argue that the impact of reserved seats 'beyond numbers' crucially depends on the party affiliation of the minority representative. Party affiliation moderates the impact of reserved seats on substantive representation since minority and party constituencies can cross-pressure a representative or, in the case of overlap, can allow her to cater to party and minority interests simultaneously. 
Drawing on empirical examples, I first classify party affiliations along the criterion of overlap between minority interests and party appeal into five categories: 'coinciding ethnic' parties, 'multi-ethnic' parties, 'partial ethnic' parties, 'other ethnic' parties, and 'non-ethnic' parties. I then develop hypotheses on how these affiliations affect a reserved-seat representative's willingness to act for the minority. ${ }^{2}$ I expect a strong positive effect of coinciding ethnic parties, a weak positive effect for multi- and partial ethnic parties, a negative effect for other ethnic parties, and no systematic effect for non-ethnic party affiliation.

The section 'Reserved Seats and Minority Representation' conceptualises reserved seats and minority representation and describes the causal mechanism connecting them. The section 'The Party Affiliation Hypothesis ' then introduces possible relationships between minority interests and party appeal, which form the basis for deriving a set of hypotheses on how these constellations affect the willingness of a representative to act in the interests of the minority she descriptively represents. The section 'Conclusion' concludes this article.

\section{Reserved Seats and Minority Representation}

To conceptualise the outcome of minority representation, Pitkin's (1967) four-dimensional analysis of the concept of representation constitutes an adequate point of departure, since she differentiates descriptive representation-which should follow automatically from introducing reserved seats ${ }^{3}$ - from substantive representation, for which the effects of reservations are less straight forward. Pitkin (1967, pp. 80-81, citing Griffiths \& Wollheim, 1960, p. 188) defines descriptive representation as when 'a person or thing stands for others "by being sufficiently like them". . She argues that while this dimension of representation can sensibly be related to the purpose of providing information about the represented, it implies no direct link to substantive outcomes.

By contrast, the notion of substantive representation as 'substantive acting for others' (Pitkin, 1967, p. 115) is defined as follows:

The representative must act in such a way that, although he is independent, and his constituents are capable of action and judgment, no conflict arises between them. He must act in their interest, and this means that he must not normally come into conflict with their wishes. (1967, p. 166)

Importantly, this definition contains the notion of the 'interest' of the constituents. Consequently, if we want to know whether a minority representative substantively represents, we must establish what the minority interest consists of. However, since according to social psychology ethnic identity in and of itself does not imply specific ethnic interests (Hale, 2008, p. 52), the question: 'what is the minority interest?' cannot be settled a priori (unless we are willing to return to the essentialist ontology of primordialism). Rather, the answer to the question will be contingent on the specific construction of the minority interest within a given context of majority-minority relations. Members of a minority group that is disadvantaged vis-à-vis other groups in a given society may be most concerned about achieving non-discrimination and equality of opportunities in the socio-economic realm. For members of another minority group, concerns about how to best preserve the minority culture may take priority. Since I am here discussing the relationship between 
reserved seats and substantive representation at the theoretical level, I will rely on two simplifying assumptions: (1) the ontological assumption that distinctive minority interests exist and (2) the epistemological assumption that representatives can distinguish them from the interests of other societal groups. These assumptions may or may not hold within a given context. ${ }^{4}$

The article further focuses more narrowly on a pre-condition for substantive representation, developing hypotheses for when a minority representative is likely to be at least willing to act in the interest of the minority she is supposed to represent according to her mandate. Whether she can actually do something in the interest of the minority depends on a number of further factors such as, inter alia, the size of the minority group within a given community, the total number of minority representatives within the decision-making body, and whether they are included or not included in governing coalitions or needed to support a minority government (for the latter, see Bird, 2014, p. 23).

Upon conceptualising the starting condition of the causal mechanism, namely the institutional provisions aimed at ensuring descriptive representation for minority groups, reserved seats have to be distinguished from candidate quotas that operate within political parties. According to Htun (2004, p. 440), legislative reservations:

set aside a fixed percentage of legislative seats for members of a certain group. These may be filled through competitive election in specially created districts (Scheduled Castes and Scheduled Tribes in India), through election by voters registered on separate rolls (Maoris in New Zealand), by the group member receiving the most votes in general elections (constitutionally recognized ethnic groups in Mauritius), or through designation by political parties (minorities in Pakistan).

This article deals with the impact of reserved seats, since this solution is overwhelmingly used to represent ethnic minorities, while quotas are the mechanism of choice when it comes to increasing the representation of women in parliaments (Htun, 2004). ${ }^{5}$ Reserved seats secure the actual representation of the minority more directly, since they guarantee that there will be at least as many minority members in the legislature as there are seats foreseen by the reservations (Norris, 2006, p. 209). In the case of candidate quotas, the outcome in terms of the composition of the legislature is less certain and depends on whether closed lists or open lists are in use. If closed lists are used, it is crucial whether the electoral law also specifies the position on the list that should be given to minority candidates. $^{6}$

Furthermore, within the category of reserved seats, the theoretical arguments developed in this article apply exclusively to reserved seats that are filled through competitive elections. In the case of reserved seats filled through nomination, the chain of accountability connects the representative to the nominator instead of her own constituency, rendering irrelevant the discussion of cross-pressure arising from the potential incongruence of a minority and a party electorate.

Norris (2006) provides a useful scheme for laying out the mechanism that connects features of the electoral system-such as a provision for reserved seats- to representational outcomes. She argues that the electoral system and reserved seats affect the calculus of selectorates deciding about suitable candidates within political parties. In a second step, electorates then choose from the fielded candidates and determine who enters the 
parliament (Norris, 2006, p. 204). Norris opens up the black box between the introduction of reserved seats as an element of the electoral system and representative outcomes by focusing on the role played by selectorates within political parties. This points our attention to the fact that even when it comes to selecting representatives to reserved seats on the basis of their identity, these candidates are not all alike, and an important characteristic in which they differ is their party affiliation. Parties can be assumed to nominate candidates that will maximise their votes. Ceteris paribus, introducing reserved seats should increase the incentives for established political parties to field minority candidates not only on the party list, but also on the minority one, with the expectation that the minority candidate will win votes among the minority and gain additional seats the party could not otherwise obtain, namely those reserved for minority candidates. Reserved seats can thereby increase the chances that aspirants with a minority identity will be seen as viable candidates by the party selectorate.

Norris' (2006) causal scheme stops at descriptive representation (i.e. the composition of the parliament). Descriptive representation is, however, neither a necessary nor a sufficient condition for substantive representation since (a) we can think of representatives who are not members of a minority in terms of their ethnic identity, but nonetheless decide to defend the minority's interests and (b) we can think of representatives who resemble the minority group descriptively, but decide to do nothing that targets the minority group specifically. The mechanism initiated by introducing reserved seats is therefore fully determined only to the point of the composition of the elected body in question.

Whereas descriptive representation is established as a consequence of the electoral phase, substantive representation in the sense of the representative acting for the minorities takes place during the inter-electoral phase. ${ }^{7}$ Only the latter lays a basis on which a minority constituency can hold its representative accountable (Urbinati \& Warren, 2008, p. 401). During the inter-electoral phase, minority representatives have several options at their disposal to represent minority interests in a substantive way: they may voice the demands of minorities during parliamentary debates, may join governing coalitions, and ultimately propose and decide on public policies. Importantly, however, whether they will have incentives to do so is likely to be affected by their party affiliation. Party affiliation thereby establishes a (empirically contingent) link between the part of the mechanism where parties decide whether to field minority candidates (and which is directly affected by reservations) and the potential outcome of substantive representation (which does not directly follow from electoral rules).

\section{The Party Affiliation Hypothesis}

The discussion so far has shown that sharing the characteristics of a minority does not imply that representatives will also be willing to act in the interests of those they descriptively represent during the inter-electoral phase. I will, however, in the following develop a set of party affiliation hypotheses that connect the candidate nomination decisions made by political parties during the electoral phase to a representative's willingness to act in the interests of those she has a mandate to represent in the inter-electoral phase. The argument is that whether a descriptive representative's ethnic constituency and party constituency overlap, cross-cut, or exclude each other can make her more or less likely to be willing to act in the interests of the minority-leaving aside whether she will subsequently be able to actually influence policy output, and assuming (1) that it is clear to everyone 
that minority interests exist and of what they consist and (2) that the overall electoral system remains constant. ${ }^{8}$ Recent findings from scholars studying the substantive effects of reservations in India (Dunning \& Nilekani, 2013; Jensenius, 2013) and Bosnia and Herzegovian (Hodžić, 2011) point out that different party affiliations differently affect substantive representation depending on whether minority interests and party appeal coincide, that is, whether the party and the minority constituency place competing expectations on the representative. The authors do not explore the impact of the full variety of different party memberships that minority representatives can have, since they are primarily concerned with the features of their cases. Extending their insights to cover the scope of possible party affiliations minority representatives can have leads to six possibilities:

(1) no party affiliation (independent candidate);

(2) 'coinciding ethnic' party affiliation;

(3) 'multi-ethnic' party affiliation;

(4) 'partial ethnic' party affiliation;

(5) 'other ethnic' party affiliation;

(6) 'non-ethnic' party affiliation. ${ }^{9}$

These different party affiliations of the minority representative function as an important moderator of the overall relationship between reserved seats and substantive representation. ${ }^{10}$ To be able to theorise in detail about how these possible affiliations moderate the willingness of the minority representative to substantively represent the minority, the concept of an ethnic party needs to be defined. For the purpose of the argument from party affiliation, an appeal-based definition of ethnic parties such as the one suggested by Chandra (2004) provides more conceptual clarity than a support-based definition:

An ethnic party is a party that overtly represents itself as a champion of the cause of one particular ethnic category or set of categories to the exclusion of others, and that makes such a representation central to its strategy of mobilizing. (Chandra, 2004, p. 3, original italics)

With an appeal-based definition of an ethnic party, we can directly infer whether the party's appeal coincides or conflicts with minority interests.

The following paragraphs now discuss each of these party affiliations in turn and suggest hypotheses about how they affect the likelihood that representatives will be willing to act in the interests of the minority they descriptively represent. Figure 1 displays the possible relationships between party appeal and minority interest through a set of Venn diagrams while Table 1 summarises all hypotheses.

(1) No party and (2) 'coinciding ethnic' parties. The clearest positive effect of party affiliation on substantive representation can be expected in constellations where either there is no party appeal that could conflict with the minority interest or the minority interest is a direct source of party organisation. The former constellation is obtained in the case of an independent candidate. The latter constellation is obtained in cases where the minority representative is a member of an ethnic minority party that appeals explicitly to the minority group and where minority interest and party appeal are therefore congruent 
coinciding ethnic party

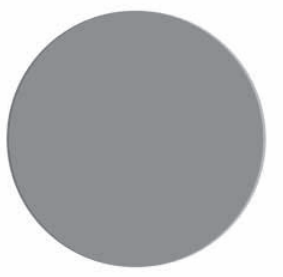

other ethnic party

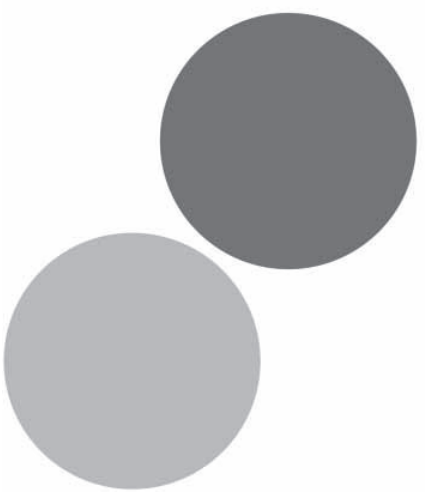

multi-ethnic party

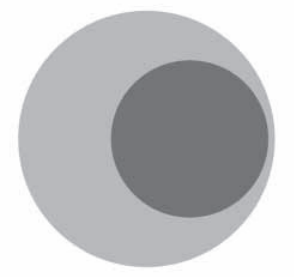

non-ethnic party

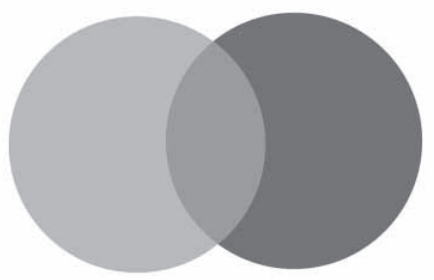

Figure 1. Party appeal and minority interest partial ethnic party

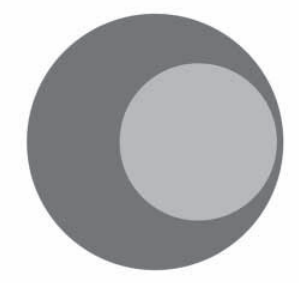

party appeal

minority interest

(cf. upper left corner of Figure 1). An example of this is the representation of the Serbian minority in the Croatian Parliament where eight seats are reserved for minorities (Lončar, 2011, pp. 141-142). Out of these eight seats, three are reserved for minorities that make up more than $1.5 \%$ of the population (Article 19, Paragraph 2, Constitutional National Minority Rights Act, 2002), a condition that is in practice only met by the Serbian minority. All three Serbian minority representatives in the current legislature are members of the same Serbian ethnic minority party, the SDSS (Samostalna demokratska srpska stranka, or Independent Democratic Serbian Party) and form their own parliamentary group (Hrvatski Sabor, 2014). Representatives affiliated with ethnic minority parties should further the minority's interests most strongly, compared to representatives affiliated with other parties. This is because, regardless of the line along which the representative seeks to further her constituents' interests (party supporters or minority group), she will always

Table 1. Summary of hypotheses

Party affiliation of minority representative
Hypothesised effect upon the willingness to act for minorities

\section{Positive}

Positive, but weak

Partially positive (for a fraction of the minority)

Negative

Depends on party programme 
act in the interests of the minority. Independent candidates decide to run for reserved seats because they identify with the minority group and do so with a programme appealing to the minority. They therefore resemble a one-person ethnic minority party and are functionally equivalent with regard to the hypothesised effect. The self-perceptions of local MPs in the Bosnian municipality of Livno illustrate this hypothesis. Those MPs affiliated with an ethnic party see themselves as being primarily responsible for advancing ethnic interests of 'their' community, whereas a member of the non-ethnic party, SDP (Socijaldemokratska partija or the Social-Democratic Party), in this municipality does not see ethnic representation as a primary concern (see Hodžić and Mraović in this Special Section).

(3) 'Multi-ethnic' parties. Let us next consider the case where the constituency, which the minority representative should represent according to her party membership, is larger than, and therefore includes, the ethnic constituency of the minority representative (cf. upper middle part of Figure 1). This would be the case in a multi-ethnic party that openly seeks to represent the interests of not one but all groups in the society. Minority representatives affiliated with a multi-ethnic party should further the interests of all groups appealed to by the party, defining their representational roles more broadly and inclusively than merely acting on behalf of minorities. Consequently, there should be a positive effect on the willingness to act for minorities, but only weakly, since minorities' interests will not be targeted specifically, but only, inter alia, alongside the interests of the other societal groups that constitute the multi-ethnic constituency of the party. This is reflected in the opinion minority political activists in the Bosnian municipality of Živinice expressed about minority MPs affiliated with a multi-ethnic party: they perceived them as being only 'symbolic', rather than substantive representatives and expected them to be bound by the allegiance to their party, rather than the minority (see Hodžić and Mraović in this Special Section). This is in line with findings from India. Having established that reserving the office of the village council president has no effect on the likelihood that members of scheduled castes/tribes will report having received benefits, Dunning and Nilekani (2013) hypothesise that 'linkages between upper and lower caste council members within multi-caste party organisations may create incentives for allocating benefits to both upper and lower caste party members, regardless of the presence or absence of quotas' (2013, p. 49). They then show in a subsequent test that unlike being a member of the same caste, being a member of the same multi-caste party as the council president significantly raises the likelihood of individuals' reporting to have received benefits.

(4) 'Partial ethnic' parties. An additional possibility would be for the minority constituency to include, but be wider than, the constituency to which the representative's ethnic party seeks to appeal (cf. upper right part of Figure 1). This could be the case if seats are reserved for an overarching identity category like in Bosnia, where seats are reserved for representatives of 'national minorities' rather than specific groups at the local level, but the representative is a member of a party with a platform representing only one of these groups (e.g. a Roma party). A similar constellation may arise in cases of reserved seats for indigenous people in Bolivia and Peru. 'Indigenous' is a higher order identity category, 'encompassing thousands of distinct groups, which in Latin America include speakers of a few hundred different languages, highland and lowland dwellers, rural and urban residents, different class backgrounds, and people with varying identities' (Htun \& Ossa, 2013, pp. 6-7). Indigenous identity is further less salient for individuals than their specific ethnic group identity (e.g. Aymara or Quechua) (Htun \& Ossa, 2013, p. 13). 
Correspondingly, indigenous organisations had originally demanded a seat for each constitutionally recognised specific group, rather than seats for the generic category of 'indigenous' (Htun \& Ossa, 2013, p. 5). The hypothesis suggested for partial ethnic parties is that the representative will be willing to act in the interest of only a fraction of the group for which seats are reserved: the fraction to which her party appeals.

(5) 'Other ethnic' parties. Rather than the party's appeal including (multi-ethnic) or at least partially coinciding (partial ethnic) with the minority identity category for which seats are reserved, there is the possibility that the minority representative is affiliated with an ethnic party that appeals to another ethnic group (cf. bottom left part of Figure 1). This may happen in democracies where ethnicity is such a dominant force in politics that all mainstream parties are also ethnic parties, and where these parties may strategically nominate minority candidates even though these candidates do not match the parties' ethnic appeal (Hodžić, 2011, p. 26). In Bosnia and Herzegovina, the most powerful mainstream parties are ethnic parties representing the three constituent people, Bosniaks, Croats, and Serbs. Minority representatives affiliated with these mainstream parties face a problem of 'double representation - the representation of party interests and the representation of minority interests-that [...] obviously goes at the expense of minorities' (Hodžić, 2011, p. 27, emphasis added). Since representing the party line in this case means targeting another ethnic group, the minority representative should be under the strongest cross-pressure. Acting in favour of the ethnic party will, by virtue of the exclusivity of ethnic appeals, preclude acting in favour of ethnic groups not targeted by the party. According to the insights from the Indian case, minority representatives can be expected to resolve this conflict in favour of the party. In this case, we could therefore hypothesise a negative impact on the representative's willingness to act in the interest of minorities.

(6) 'Non-ethnic' parties. A final constellation occurs in the case where minority representatives are nominated by non-ethnic parties, that is, parties that appeal to voters irrespective of their ethnic identity. In this case, since the party platform has no specific aim to advance the interests of one, several, or all ethnic groups in the society, but rather appeals to voters on grounds other than their ethnicity, no a priori expectation can be deduced regarding the effect of the representative's affiliation with this party on her willingness to foster minority interests. For example, a minority representative affiliated with a non-ethnic party with a social democratic programme might act in the interest of poorer minority group members by advocating for welfare redistribution, but the same representative would thereby act in conflict with the interest of entrepreneurial members of the minority group. In short, since ethnic appeal cannot serve as a theoretical short-cut for assuming a relationship between party and minority interest, the relationship between a non-ethnic party and minority interest is highly contingent on the actual content of the minority interest and the actual content of the party programme in a given case and the size of the intersection between the two (cf. Figure 1) will be a function of this. Examples of this constellation can be found in the cases of Albanian representation in Montenegro and Maori representation in New Zealand. In Montenegro, five seats in the national parliament are reserved for representatives of the Albanian minority who are elected in a special minority district. Since any political party can field candidates for the Albanian minority district, one out of five Albanian minority seats was gained by a representative from the non-ethnic DPS (Demokratska partija socijalista or Democratic Party of Socialists) in 2009 (Lončar, 2011, p. 143). New Zealand reserves seven seats 
for Maori in its national parliament, and as in the case of Montenegro these are elected in a special, nation-wide district (Bird, 2014, p. 17). From 1930 until 2002 (with the exception of 1996), the Labour party, that is, a non-ethnic party, always succeeded in having its candidates elected to all seven Maori seats. This changed in 2005 when four out of seven seats went to candidates from a Maori ethnic party. The success of the Maori party was explained by the perception that Labour candidates were not independent enough to truly represent Maori interests (Geddis, 2006, p. 350).

Empirical investigations are now needed to test the party affiliation hypotheses developed here, exploring which kind of party affiliation is indeed most conducive to yield representatives willing to act in the interest of the group for which the seats were reserved. The examples provided for each party affiliation show that all six constellations occur empirically within the universe of reserved seats. This allows researchers to choose from a variety of cases to test the hypotheses suggested here in the future. Naturally, constellations will not all play an equally important role in each country due to legal restrictions as to who can field candidates for minority seats; so researchers need to make sure there is enough variance in party affiliation across the cases they study. However, even in cases like Romania - where the electoral law foresees only ethnic minority parties to field candidates for the reserved seats (cf. Meier, 2009, p. 6) -we should be aware that functional equivalents to 'non-ethnic' or 'multi-ethnic' parties fielding candidates for these seats may exist and that constellations in practice may exceed those foreseen by electoral laws. For example, 'non-ethnic' parties may first found and sponsor a minority organisation to then have this organisation field 'their' preferred candidates in the minority election, which is something that happened in the elections for the national minority councils in Serbia in 2010 (Zuber \& Mus, 2013, pp. 7-8). For Romania, Alionescu (2004, p. 69) discusses the case of a leader of a syndicate of coal miners (i.e. a non-ethnic organisation) who founded an ethnic Macedonian party to enter parliament in 2000 as a minority MP in a reserved seat. He received 8809 votes despite the fact that in the 2002 census only 751 people declared themselves as Macedonians.

In addition, researchers need to take into account that reserved seats are institutions that are difficult to compare due to the idiosyncrasies of the formula applied (Meier, 2009; for a similar verdict about electoral mechanisms for group representation more generally, see Vukelic, 2012). In light of this, the advantage of the party affiliation hypotheses is that it can be tested by comparing the behaviour of reserved seat representatives affiliated with different parties within the same electoral system. Single case studies could trace the causal process from the introduction of the reserved seats in a given country through the adaptation of party strategies to representational outcomes. Small N studies could compare the representational roles and the evaluation of representational activities of reserved seat MPs affiliated with different parties given the same electoral formula for reserved seats. The latter research design is pursued in the third paper of this Special Section. The selected cases of minority representation in four municipalities that apply reserved seats maximise variance in party affiliation of the minority representative: the Croat minority representative in Brčko (where Croats constitute a local minority) is affiliated with a 'coinciding ethnic' party, the Croatian Democratic Union (Hrvatska demokratska zajednica, HDZ); minorities in Prnjavor are represented by an independent; the minority representative in Prijedor is from a 'multi-ethnic' party (SDP); and the (nonSerb) minority representative in Gradiška is from an 'other ethnic' party, the Serbian Alliance of Independent Social Democrats (Savez nezavisnih socijaldemokrata, SNSD). 
For a large $\mathrm{N}$ study, minority representatives in reserved seats could be surveyed about their party affiliation and about how they see their own representational role (i.e. rather as representing one ethnic minority, minorities in general, all citizens, the party voters, etc.). Controlling for different formulae, researchers could then test how these variables affect indicators for the actual representational activity of minority MPs (e.g. the share of parliamentary interventions made on behalf of minority interests).

\section{Conclusion}

This article has aimed to clarify the relationship between reserved seats, party affiliation, and minority representation. I have first tried to describe (in rather broad strokes) the causal mechanism linking reserved seats to the substantive representation of minority interests. I have then extracted one part of the mechanism - that which connects parties nominating candidates to candidates seeking to foster the interests of minorities-for a more in-depth theoretical investigation. I have shown that upon theoretical grounds, six party affiliations of minority representatives are possible and I have developed hypotheses of how these affiliations affect substantive representation. I have argued that (ceteris paribus) we can expect that a minority representative's actions will be more likely in conflict with the wishes of the minority constituents if she serves a party with an appeal that cross-cuts or even excludes the minority than if she is independent or a member of an ethnic party appealing directly to voters on the basis of the same ethnic identity. Party affiliation is likely to affect what a representative does and is therefore a relevant characteristic to be taken into account when studying the substantive effects of reserved seats (cf. Pitkin, 1967, p. 142). The discussion was here limited to a pre-condition of substantive representation (in the sense of actual representative activity), the willingness of a minority representative to indeed choose the representative role of acting in the interest of the minority. However, party affiliation can also be expected to determine where representatives will target their actual activities; whether they will primarily seek to influence the position of their 'multi-ethnic' or 'other ethnic' party, or whether they will, in the case of an independent representative or as a member of a 'coinciding ethnic' party, directly negotiate with other members of the local assembly.

This article has taken the party-society linkage as a given and has hypothesised about how different party affiliations affect the willingness of minority representatives to further minority interests. However, it should be noted that this static view on institutions, identities, and interests seems only plausible in the short run and falls short of reflecting the endogeneity between institutions, identities, and interests that comes to the fore once we adopt a temporal perspective. Constructivist theorists of ethnic identity (Brubaker, 2004; Chandra, 2006) remind us that in the long run, institutions themselves have an impact on the way social groups are defined and that rather than merely representing the already given interests of clearly demarcated social groups, political elites themselves can emphasise one set of social identity categories (such as ethnicity) over others (e.g. social class), thereby heightening one identity's salience in public discourse and raising the value of the 'groupness variable'. ${ }^{11}$ Unlike candidate quotas that aim to overcome differences by tackling them within the existing party system, reserved seats emphasise and institutionalise difference. ${ }^{12}$ Reserved seats provide the stable institutional rule that identifying with a particular identity category yields political payoffs in terms of office, thereby strengthening voters' ethnic identification and encouraging the development of 
ethnic minority parties (Htun, 2004, p. 439; see also Van Cott, 2003). ${ }^{13}$ A dilemma of competing societal goals may thus emerge: in order for quotas to really improve life for disadvantaged ethnic minority groups, representatives should be from ethnic minority parties so that the ethnic and the party constituencies are congruent. From the perspective of the goal of substantive minority representation, it should therefore be welcome that quotas set incentives for the formation of ethnic parties at the level of minority groups. However, in order for a multi-ethnic society to remain cohesive rather than disintegrate along ethnic lines, the exact opposite is needed: parties that cross-cut ethnic identity categories, seeking to cater to the interests of voters from different ethnic groups alike and voters that define their interests not merely along the lines of ethnic identity, but along the lines of multiple social identity categories.

\section{Acknowledgements}

An early version of this article was presented at the Institute of Political Science of the University of Zurich, 14 May 2013, and at the SCOPES Workshop in Sarajevo, 20 May 2013. A later draft was then publicly discussed at the SCOPES conference on 'Ethnodemocracy in the heart of Europe: political mobilisation and representation of ethnic groups in Bosnia and Herzegovina in a comparative perspective', in Sarajevo, 23-24 September 2013. Very helpful comments by participants on all three occasions, and in particular by Florian Bieber, Karen Bird, Daniel Bochsler, Regis Dandoy, Miriam Hänni, Edin Hodžić, Mirna Jusić, Borisa Mraović and Asim Mujkić are very gratefully acknowledged. All remaining errors are my own.

\section{Funding}

This work was supported by the Swiss National Foundation for Scientific Research, SCOPES programme [Grant number IZ73Z0_128253].

\section{Notes}

1. For ease of presentation, I will use the terms reservations and reserved seats to refer to reserved seats filled through competitive elections in either a special minority district or on a special minority ballot in the remainder of this article.

2. Whereas the descriptive classification of possible party affiliations can be used in studies of minority representation in party democracy per se, the scope of the causal hypotheses is limited to minority representatives in reserved seats. Only if the minority representative has an explicit mandate to represent the minority can we have a reasonable theoretical expectation of cross-pressure. By contrast, we cannot a priori expect an ordinary MP of political party A to be under pressure to also represent minority B, just because she descriptively belongs to B (unless we are willing to make the academically disqualified primordial assumption that ethnic identity equals ethnic interests). We can, however, expect this from an MP in a seat with an explicit mandate to represent B.

3. Though this should not be taken for granted since if the electoral provisions for the reserved seats allow all political parties to field candidates, candidates who do not share the descriptive characteristics of the minority group may be elected (Meier, 2009). For example, in the Montenegrin parliament in the years 2006, 2002, 2001, and 1998, only two out of the five seats reserved for the Albanian minority were indeed held by Albanian representatives (Lončar, 2011, p. 143).

4. Hodžić and Mraović (this Special Section) solve this problem by asking members of the minority communities in a given municipal context whether they feel represented by the minority representative holding the reserved seat, rather than applying an a priori definition of 'the minority interest'. 
5. Htun (2004, p. 441) also provides an explanation for this empirical pattern. She argues that gender crosscuts partisan affiliations whereas ethnic identity tends to be a direct basis for mobilisation and will therefore overlap with partisan cleavages. Consequently, women can be represented by forcing the parties they are already affiliated with to field them as candidates, whereas minority groups can be represented through their own ethnic parties thanks to reserved seats.

6. On the basis of a concise taxonomy of the procedural rules for ethnic quotas applied for elections to the national parliament in 28 countries, Bird (2014, p. 13) suggests a classification of three families of ethnic quota systems: 'systems guaranteeing seats to ethnic parties, systems incorporating designated ethnic groups within pan-ethnic parties and systems involving special electoral districts for ethnic groups'. This article deals exclusively with Bird's third family of special districts for ethnic groups. This limitation allows me to formulate more concise theoretical expectations, given the substantive differences between the three families.

7. According to Benoit and Laver (2006, p. 37),

we can think of political competition as a continuous process that is structured into two distinct phases by two institutional automata-an electoral system and a legally mandated maximum inter-election period. [... ] They distinguish what we might think of as the 'electoral' phase of political competition from the 'inter-electoral' phase.

8. In statistical terminology, I am thus theorising the partial effect of different party affiliations when controlling for the electoral system and other contextual features. A detailed discussion of the complex interaction between overall electoral system design and reserved seats is beyond the scope of this article. This is an important aspect deserving further investigation.

9. Of course under any given electoral system with provisions for reserved seats, not all of these constellations might be possible, since there might be requirements about the type of party/organisation entitled to nominate candidates for the minority seats.

10. In their seminal distinction of moderators and mediators, Baron and Kenny (1986, p. 1174) define a moderator as follows: '[A] moderator is a qualitative (e.g. sex, race, class) or quantitative (e.g. level of reward) variable that affects the direction and/or strength of the relation between an independent or predictor variable and a dependent or criterion variable'.

11. On groupness as a variable rather than a constant, see Brubaker (2004, pp. 3-4).

12. In the terminology of rational choice institutionalism, we could say that reserved seats are 'self-re-enforcing', whereas candidate quotas are 'self-undermining' institutions (Greif \& Laitin, 2004, p. 634).

13. It should be noted, however, that the extent to which reserved seats really contain essentialising features is contingent on the criteria for entitlement to stand for (respectively vote for) reserved seats in a given case, as argued by Meier (2009) on the basis of a thorough overview of candidacy and voter requirements in 13 cases of reserved seats in national legislatures.

\section{References}

Alionescu, C. C. (2004). Parliamentary representation of minorities in Romania. Southeast European Politics, $5(1), 60-75$.

Baron, R. M., \& Kenny, D. A. (1986). The moderator-mediator variable distinction in social psychological research: Conceptual, strategic, and statistical considerations. Journal of Personality and Social Psychology, $51(6), 1173-1182$.

Benoit, K., \& Laver, M. (2006). Party policy in modern democracies. New York, NY: Routledge.

Bird, K. (2014). Ethnic quotas and ethnic representation worldwideč. International Political Science Review, $35(1), 12-26$.

Brubaker, R. (2004). Ethnicity without groups. Cambridge, MA: Harvard University Press.

Chandra, K. (2004). Why ethnic parties succeed: Patronage and ethnic headcounts in India. Cambridge, MA: Cambridge University Press.

Chandra, K. (2006). What is ethnic identity and does it matter? Annual Review of Political Science, 9(1), $397-424$.

Chattopadhyay, R., \& Duflo, E. (2004). Impact of reservation in Panchayati Raj: Evidence from a nationwide randomised experiment. Economic and Political Weekly, 39(9), 979-986. 
Constitutional National Minority Rights Act. (2002). [Ustavni zakon o pravima nacionalnih manjina], Narodne novine, 155/02, 80/10, 93/11. English translation. Retrieved April 9, 2014, from http://www.sabor.hr/ Default.aspx?art=2448

Duflo, E. (2005). Why political reservations? Journal of the European Economic Association, 3(2/3), 668-678.

Dunning, T., \& Nilekani, J. (2013). Ethnic quotas and political mobilization: Caste, parties, and distribution in Indian village councils. American Political Science Review, 107(1), 35-56.

Geddis, A. (2006). A dual track democracy? The symbolic role of the Maori seats in New Zealand's electoral system. Election Law Journal, 5(4), 347-371.

Greif, A., \& Laitin, D. D. (2004). A theory of endogenous institutional change. American Political Science Review, 98(4), 633-652.

Griffiths, A. P., \& Wollheim, R. (1960). Symposium: How can one person represent another? Aristotelian Society, $34,187-224$.

Hale, H. E. (2008). The foundations of ethnic politics. Separatism of states and nations in Eurasia and the world. Cambridge, MA: Cambridge University Press.

Hodžić, E. (2011). Political participation of national minorities in local governance in Bosnia and Herzegovina: State of the art, prospects and ways forward. Sarajevo: Center for Social Research Analitika.

Hrvatski Sabor. (2014). Zastupnici 7. saziva Hrvatskoga sabora [Members of Croatian Parliament, 7th legislature]. Retrieved April 9, 2014, from http://www.sabor.hr/zastupnici

Htun, M. (2004). Is gender like ethnicity? The political representation of identity groups. Perspectives on Politics, 2(3), 439-458.

Htun, M., \& Ossa, J. P. (2013). Political inclusion of marginalized groups: Indigenous reservations and gender parity in Bolivia. Politics, Groups, and Identities, 1(1), 4-25.

Jensenius, F. R. (2013). Power, performance and bias: Evaluating the electoral quotas for scheduled castes in India. Berkeley: University of California.

Krook, M. L., \& O’Brien, D. Z. (2010). The politics of group representation: Quotas for women and minorities worldwide. Comparative Politics, 42(3), 253-272.

Krook, M. L., \& Zetterberg, P. (2014). Electoral quotas and political representation: Comparative perspectives. International Political Science Review, 35(1), 3-11.

Lončar, J. (2011). Izborna formula i reprezentacija manjina. In Z. Stojiljković \& D. Spasojević (Eds.), Preporuke za izmenu izbornog zakonodavstva u Srbiji [Recommendations for an electoral law reform in Serbia] (pp. 137-149). Belgrade: National Democratic Institute for International Affairs Serbia.

Lončar, J. (in press). Power-sharing in Kosovo: Effects of ethnic quotas and minority veto. In J. Teokarević (Ed.), Multiethnic perspectives of Kosovo.

Meier, P. (2009, September). Defining groups entitled to reserved seats in national legislatures: A comparative approach. Paper presented at the annual meeting of the American Political Science Association, Toronto.

Norris, P. (2006). The impact of electoral reform on women's representation. Acta Politica, 41, 197-213.

Pitkin, H. F. (1967). The concept of representation. Berkeley, CA: University of California Press.

Reynolds, A. (2005). Reserved seats in national legislatures: A research note. Legislative Studies Quarterly, 30(2), 301-310.

Urbinati, N., \& Warren, M. E. (2008). The concept of representation in contemporary democratic theory. Annual Review of Political Science, 11, 387-412.

Van Cott, D. L. (2003). Institutional change and ethnic parties in South America. Latin American Politics and Society, 45(2), 1-39.

Vukelic, K. (2012). Designing special electoral mechanisms for group representation (Master's, thesis). Central European University, Budapest, Hungary. Retrieved March 16, 2015, from http://www.etd.ceu.hu/2012/ vukelic_kristijan.pdf

Zuber, C. I., \& Mus, J. J. (2013). Representative claims and expected gains: Minority council elections and intraethnic competition in Serbia. East European Politics, 29(1), 52-68. 